\title{
Variability in periphyton community and biomass over 37 years in Lake Tahoe (CA-NV)
}

\author{
Karen S. Atkins $(\mathbb{D} \cdot$ Scott H. Hackley $\cdot$ Brant C. Allen $\cdot$ Shohei Watanabe • \\ John E. Reuter $\cdot$ S. Geoffrey Schladow
}

Received: 7 August 2020/Revised: 24 January 2021/Accepted: 2 February 2021 / Published online: 26 February 2021

(C) The Author(s) 2021

\begin{abstract}
Nuisance periphyton blooms are occurring in oligotrophic lakes worldwide, but few lakes have documented changes in biomass through periphyton monitoring. For decades periphyton has caused concern about oligotrophic Lake Tahoe's nearshore water quality. To determine whether eulittoral periphyton increased in Lake Tahoe, measures of biomass and dominant communities at $0.5 \mathrm{~m}$ below lake level have been monitored regularly at nine shoreline sites starting in 1982, with up to 54 additional sites monitored annually at peak biomass. Lake-wide, this metric of periphyton biomass has not increased since monitoring began. Biomass decreased at many sites and increased at one. Periphyton biomass peaked in March and was low in the summer lake-wide. The northern and western shores had higher biomass than the eastern and southern shores. Biomass varied with lake level. High biomass occurred at sites regardless of urban development levels. As increasing periphyton at Lake Tahoe was first cited in scientific literature in the
\end{abstract}

Handling editor: David Philip Hamilton

K. S. Atkins $(\bowtie) \cdot$ S. H. Hackley $\cdot$ B.

C. Allen - S. Watanabe - J. E. Reuter - S. G. Schladow

Tahoe Environmental Research Center, University of

California, Davis, Davis, USA

e-mail: ksatkins@ucdavis.edu

\section{K. S. Atkins}

Hydrologic Sciences Graduate Group, University of California, Davis, Davis, USA 1960s, it is possible that periphyton increased prior to our monitoring program. A dearth of published longterm monitoring data from oligotrophic lakes with reported periphyton blooms makes it difficult to determine the extent of this issue worldwide. Longterm nearshore monitoring is crucial for tracking and understanding periphyton blooms.

Keywords Benthic algae - Filamentous algae bloom - Stalked diatom · Eutrophication · Littoral · Synoptic monitoring $\cdot$ Temporal trends

\section{Introduction}

The nearshore regions of lakes are directly connected to the upland watershed. As a result, nearshore environments are influenced by land-use change, pollutant loading, erosion, and resource overuse which can all lead to eutrophication (Beeton, 2002). Periphyton serve as indicators of ecosystem function in the littoral zone and, along with phytoplankton, are the base of the food web in freshwater lake systems (Hecky \& Hesslein, 1995; Yoshii, 1999). Periphyton are often easily visible from the shoreline, react rapidly to changing conditions, and play a critical role in many lake processes including nutrient cycling, energy flow, and food web interactions (Axler \& Reuter, 1996; Vadeboncoeur \& Steinman, 2002; Denicola \& Kelly, 2013). Changes in benthic algal 
biomass can be used to distinguish areas of environmental stress, where biomass in a part of the lake shoreline deviates from the normal range of variability (Lambert et al., 2008; Spitale et al., 2014). Due to their role as an indicator and their importance for lakeecosystem health, it is important to evaluate temporal and spatial variability in this community.

Nuisance periphyton blooms are large growths of mostly filamentous periphyton in the littoral zones of oligotrophic lakes that create undesirable ecological, economic, or aesthetic outcomes. These blooms have been observed in pristine lakes worldwide. These periphytic blooms occur in high light nearshore environments and are often dominated by cyanobacteria and chlorophytes. For example, in Lake Baikal, benthic blooms have mostly consisted of chlorophytes such as Ulothrix and Spirogyra (Kravtsova et al., 2014). In New Zealand, blooms have been observed in Lake Taupo, where the shallow assemblage was dominated by cyanobacteria Scytonema and $\mathrm{Di}$ chothrix, and filamentous chlorophytes (Hawes and Smith, 1994). Some blooms are also caused by invasive algae such as Didymosphenia in Lake Hövsgöl, Mongolia (Cantonati et al., 2016). In the USA, blooms have been observed in Lake Chelan, WA, and were primarily composed of diatoms including Achnanthes and Gomphonema and filamentous green algae including Ulothrix and Cladophora (Jacoby et al., 1991). Despite wide-spread periphyton blooms over the past several decades, there are few long-term littoral monitoring programs. Lake Baikal and the Laurentian Great Lakes are examples of lakes with littoral monitoring programs capable of detecting changes in the periphyton biomass and community composition (Higgins et al., 2008; Kravtsova et al., 2014). As a result of the rarity of this type of program, the extent to which benthic algal blooms are occurring and their characteristics remain under reported and poorly understood.

No scientific data on periphyton in Lake Tahoe exists before major anthropogenic disturbance reached the lake in the 1950s and 60s in the form of large-scale development of infrastructure, homes, ski resorts, and the expansion of the casino industry. Inputs of sediments and nutrients from widespread land development and insufficient sewage treatment and disposal practices initiated anthropogenic eutrophication of the lake (e.g., Goldman, 1974). Epilithic periphyton was first observed at nuisance levels in the eulittoral zone
(0-2 m depth) in the mid-1960s by Goldman (1967); he also noted there was little periphyton on the rocks when he began studies of the lake in the late 1950s. Initial studies of periphyton were conducted in the 1970s and 1980s (e.g. Goldman \& De Amezaga, 1975; Loeb, 1980; Loeb et al., 1983; Aloi et al., 1988; and others). Communities were made up of mixed taxa, which followed spatial and temporal patterns. In the eulittoral zone stalked diatoms (e.g. Gomphoneis) and green filamentous algae (e.g. Ulothrix) predominated (Fig. 1) (Loeb \& Reuter, 1984). This community, that was subject to both high ambient light levels and the sloughing potential of wave action.

In the sublittoral zone (greater than $2 \mathrm{~m}$ depth), nitrogen-fixing cyanobacteria such as Tolypothrix, Calothrix, Scytonema, and Nostoc dominated (Loeb, 1980; Reuter et al., 1986a, b). These communities, that survived at lower light levels and were protected from direct wave action, were only intermittently sampled during drought periods when lake levels fell by up to 2-3 $\mathrm{m}$, thereby allowing them to be sampled using the $0.5 \mathrm{~m}$ depth protocol.

Lake managers considered periphyton an important indicator of thresholds in the lake's environmental status based on these early studies, and routine monitoring began in 1982 . These data initially showed that periphyton biomass increased near the locations of urban development (Loeb, 1980; Aloi, 1986). This review of the entire long-term Lake Tahoe periphyton monitoring data set addresses variability in nearshore periphyton from the early 1980 s to the present day. In most cases funding for explanatory data for assessing potential drivers was not provided.

This paper evaluates long-term trends in periphyton growth in the splash zone of Lake Tahoe over a period of decades and addresses several questions: (1) Has periphyton biomass increased since monitoring began in 1982? (2) Is there a seasonal component to biomass accumulation? (3) Is the largest periphyton growth occurring near highly developed areas? (4) Is the peak yearly biomass that is visible from the shore affected by various periphyton communities that exist at different lake levels? Compared to many systems, Lake Tahoe has a long record of consistent periphyton measurements, making it ideal for evaluating longterm periphyton variability. 

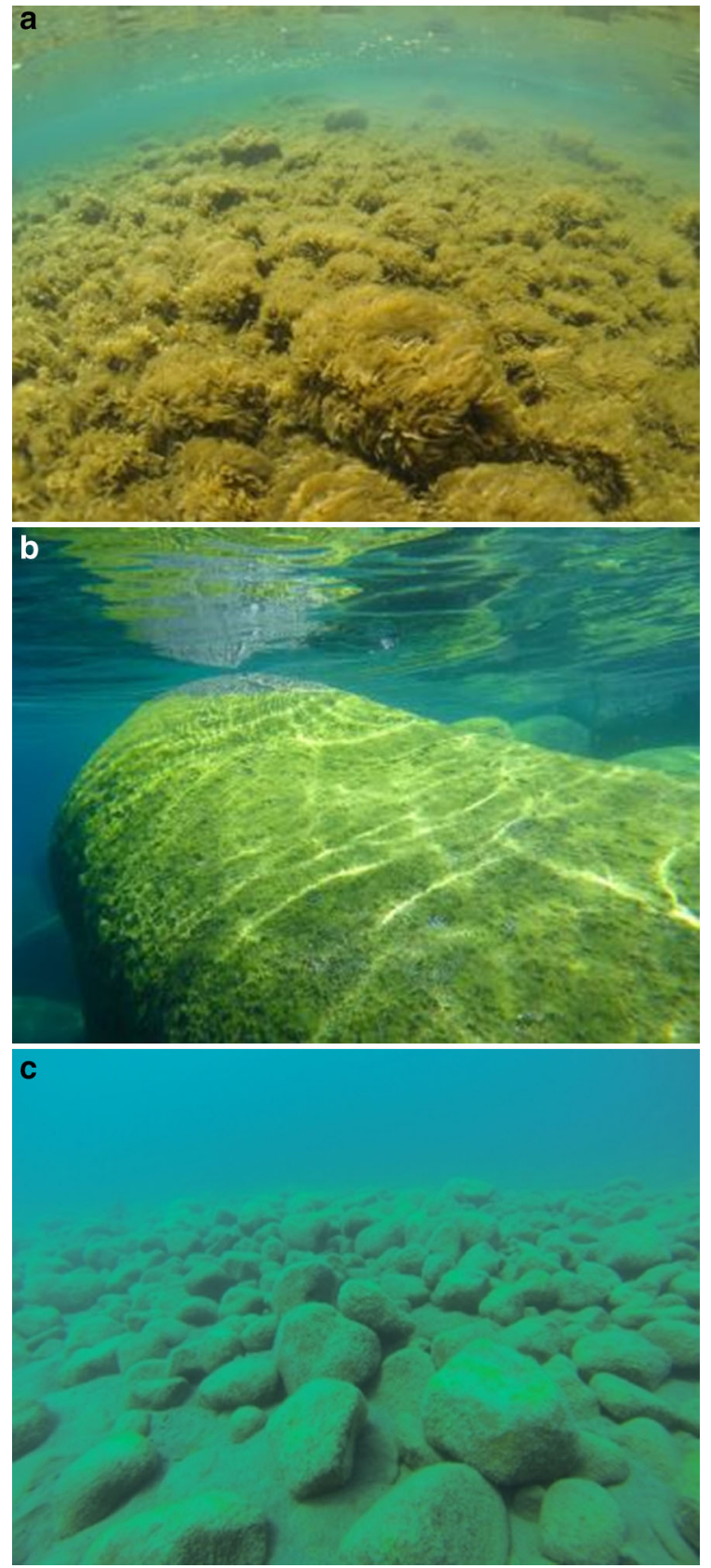

Fig. 1 Periphyton a diatoms $\mathbf{b}$ green filamentous algae, and c cyanobacteria on rocks in Lake Tahoe

\section{Methods}

Lake characteristics

Lake Tahoe is nestled in the Sierra Nevada mountain range, straddling the states of California and Nevada,
USA at an elevation of $1898 \mathrm{~m}$ amsl. It is deep, with a maximum depth of $501 \mathrm{~m}$ and a mean depth of $313 \mathrm{~m}$. It has a surface area of $499 \mathrm{~km}^{2}$ and a shoreline of $116 \mathrm{~km}$. The watershed surrounding the lake is 800 $\mathrm{km}^{2}$ with 63 inflowing streams defined by their watershed boundaries (Fig. 2) and is composed of granodiorite and andesitic volcanic rock (Hyne et al., 1972). The basin was formed by a double graben fault and therefore has steep, rocky side-slopes. The bottom substrate of the lake's south shore is almost exclusively sand. Lake Tahoe is considered oligotrophic with an average Secchi depth of $21.6 \mathrm{~m}$ in 2018, largely due to the granite basin and small watershed to lake ratio (TERC, 2019).

With a dam moderating its single outflow, Tahoe's lake level fluctuates within a total range of $2.5 \mathrm{~m}$, oscillating around 0.5 to $2 \mathrm{~m} /$ year, largely dependent on natural meteorological cycles. The lake's water

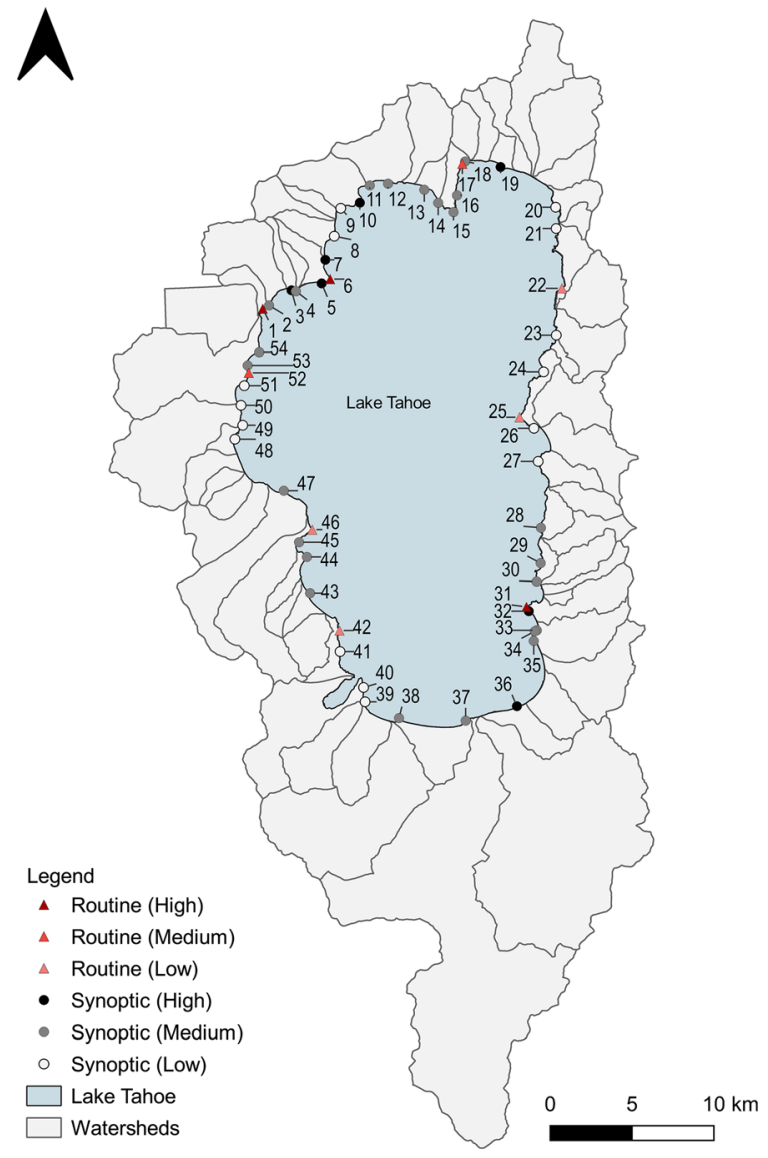

Fig. 2 Periphyton sampling locations around Lake Tahoe and thier site development level. The watershed boundaries of the 63 inflowing streams are indicated in gray 
levels cycle up and down annually with the maximum around early summer's flowing snowmelt and the minimum around early winter prior to the wet season. Drought cycles influenced the magnitude of Lake Tahoe's water level cycles during our monitoring (TERC, 2018). California experienced droughts from 1986-1992, 2006-2010, and 2011-2019 (National Drought Mitigation Center, 2020). Dry periods were also observed in the Lake Tahoe region within these periods with some wet years occurring (i.e. 1986, 2006, 2011, and 2017). The west side of the basin generally receives more precipitation and inputs of nutrients from runoff than the east side (LRWQCB and NDEP, 2010). The prevailing wind direction is out of the southwest (Roberts et al., 2019).

From the beginning of periphyton monitoring, Lake Tahoe has changed. Clarity, as measured by Secchi depth, was decreasing during the 1980s and 1990s but plateaued in the 2000s and 2010s (Tahoe Environmental Research Center, 2019). Similarly, mid-lake phosphorus levels were decreasing in the earlier period and began to increase around the year 2000 (Tahoe Environmental Research Center, 2019). Midlake nitrogen levels have been increasing since the 1980s (Tahoe Environmental Research Center, 2019).

Field and laboratory methods

To quantify periphyton in lakes, taxonomic, biomass, and metabolism analysis are commonly used. While community metabolism can be used as a proxy for growth rates in periphyton and can be useful for understanding the mechanisms of algal growth, biomass was used for monitoring at Tahoe because it was considered more relevant to biomass accumulation (Biggs \& Kilroy, 2000). Enumeration of algal genera and species was not included in this monitoring due to limited resources. Instead, gross observations of predominant periphyton types at each site were made during snorkel surveys beginning in the early 2000s.

Routine monitoring was designed to track periphyton biomass throughout the year at developed and undeveloped areas, measure algal standing crop, and evaluate long-term variability. Monitoring was conducted 29 of the past 37 years: 1982-1985, 1989-1993, and 2000-present. Surveys occurred at six to nine routine shoreline sites (Fig. 2 and Table 1), chosen to provide a range of development levels and previously observed amounts of periphyton growth.
The number of monitoring events varied through time, ranging from 3 to 15 times per year, but occurred approximately monthly between February and June which is typically the period when biomass peaks. As the exception, in the year 2004 monitoring only occurred once in October. Routine sampling included collecting data about algal biomass; percent cover; filament length; and predominant algal types present.

An increased number of synoptic sites were added to coincide with the spring biomass peak, beginning in 2003, for enhanced resolution of biomass distribution. The additional 45 synoptic sites were visited once annually to measure percent cover and algal filament length (Fig. 2 and Table 1). As a result of the spring peak occurring at slightly different times around the lake, and weather constraints on sampling, the synoptic effort may not have captured the exact peaks at all sites but generally was close to maximum biomass.

Two measures were used to assess biomass in this study: chlorophyll- $a$ (chl- $a$ ) and ash-free dry mass (AFDM). Chl- $a$ is considered an indicator of autotrophic organism biomass. We did not measure other pigments more specific to larger taxonomic groups of autotrophs. AFDM is a measure of total organic material and was included in monitoring starting in 1989. At each site, epilithic periphyton samples were collected from natural rocky substrates at a depth of $0.5 \mathrm{~m}$ below the water surface. As lake level changed, the sampling point remained $0.5 \mathrm{~m}$ below the surface. Samples of three replicates before 2000 and two replicates after 2000 were collected using two-syringe brush samplers (Loeb, 1981). These samplers collect periphyton from an area of $5.3 \mathrm{~cm}^{2}$. After collection, material was transferred from the syringes into centrifuge tubes and returned to the lab for processing the same day. Samples were centrifuged to concentrate the material, allowed to dry for an hour or more to a uniform damp consistency and then weighed, yielding total wet mass (TWM). Each sample was then rapidly split, and weighed, to provide subsamples for AFDM and chl- $a$ analysis. Chl- $a$ subsamples were stored frozen at a temperature of $-24^{\circ} \mathrm{C}$ for later analysis, and AFDM subsamples dried overnight (the drying temperature used was either $105^{\circ} \mathrm{C}$ (for data from 1989 to 1992 ) or $60^{\circ} \mathrm{C}$ (for data from 1992 to present). Use of different drying temperatures had only a small impact on AFDM estimates, as a 
Table 1 Site names, locations, frequency, geographic region, and level of development of the Lake Tahoe periphyton monitoring program

\begin{tabular}{|c|c|c|c|c|c|c|c|c|c|}
\hline Site \# & Site name & $\begin{array}{l}\text { Monitoring } \\
\text { frequency }\end{array}$ & $\begin{array}{l}\text { Lake } \\
\text { region }\end{array}$ & $\begin{array}{l}\text { Site Dev } \\
\text { Level }\end{array}$ & Site \# & Site name & $\begin{array}{l}\text { Monitoring } \\
\text { frequency }\end{array}$ & $\begin{array}{l}\text { Lake } \\
\text { region }\end{array}$ & $\begin{array}{l}\text { Site Dev } \\
\text { Level }\end{array}$ \\
\hline 1 & Tahoe City & Routine & North & High & 28 & Cave Rock & Synoptic & East & Medium \\
\hline 2 & Tahoe City Tributary & Synoptic & North & Medium & 29 & Lincoln Park & Synoptic & East & Medium \\
\hline 3 & TCPUD Boat Ramp & Synoptic & North & High & 30 & N. Zephyr Cove & Synoptic & East & Medium \\
\hline 4 & Lake Forest & Synoptic & North & Medium & 31 & Zephyr Pt & Routine & East & High \\
\hline 5 & S. Dollar Pt & Synoptic & North & High & 32 & S. Zephyr Pt & Synoptic & East & High \\
\hline 6 & Dollar Pt & Routine & North & High & 33 & Marla Bay & Synoptic & East & Medium \\
\hline 7 & S. Dollar Creek & Synoptic & North & High & 34 & N. Elk Pt & Synoptic & East & Medium \\
\hline 8 & Cedar Flat & Synoptic & North & Low & 35 & S. Elk Pt & Synoptic & East & Medium \\
\hline 9 & Garwoods & Synoptic & North & Low & 36 & Timber Cove & Synoptic & South & High \\
\hline 10 & Flick Pt & Synoptic & North & High & 37 & Tahoe Keys Entrance & Synoptic & South & Medium \\
\hline 11 & Stag Avenue & Synoptic & North & Medium & 38 & Kiva Pt & Synoptic & South & Medium \\
\hline 12 & Agatam & Synoptic & North & Medium & 39 & Cascade Creek & Synoptic & South & Low \\
\hline 13 & Kings Beach & Synoptic & North & Medium & 40 & S. Eagle Pt & Synoptic & South & Low \\
\hline 14 & Brockway Springs & Synoptic & North & Medium & 41 & E. Bay/Rubicon & Synoptic & West & Low \\
\hline 15 & N. Stateline Pt & Synoptic & North & Medium & 42 & Rubicon Pt & Routine & West & Low \\
\hline 16 & Stillwater Cove & Synoptic & North & Medium & 43 & Gold Coast & Synoptic & West & Medium \\
\hline 17 & Incline West & Routine & North & Medium & 44 & S. Meeks Pt & Synoptic & West & Medium \\
\hline 18 & Incline Condo & Synoptic & North & Medium & 45 & N. Meeks Bay & Synoptic & West & Medium \\
\hline 19 & Burnt Cedar Beach & Synoptic & North & High & 46 & Sugar Pine Pt & Routine & West & Low \\
\hline 20 & Hidden Beach & Synoptic & East & Low & 47 & Tahoma & Synoptic & West & Medium \\
\hline 21 & Observation Pt & Synoptic & East & Low & 48 & S. Fleur Du Lac & Synoptic & West & Low \\
\hline 22 & Sand Pt & Routine & East & Low & 49 & Blackwood Creek & Synoptic & West & Low \\
\hline 23 & Chimney & Synoptic & East & Low & 50 & Kaspian Pt & Synoptic & West & Low \\
\hline 24 & Skunk Harbor & Synoptic & East & Low & 51 & Ward Creek & Synoptic & West & Low \\
\hline 25 & Deadman Pt & Routine & East & Low & 52 & Pineland & Routine & West & Medium \\
\hline 26 & S. Deadman Pt & Synoptic & East & Low & 53 & N. Sunnyside & Synoptic & West & Medium \\
\hline 27 & S. Glenbrook & Synoptic & East & Low & 54 & Tavern Pt & Synoptic & West & Medium \\
\hline
\end{tabular}

Point is abbreviated as Pt. Synoptic sites were monitored annually around the time of peak biomass, whereas routine sites were monitored approximately monthly. Site development level was based on the percent impervious coverage for nearby shore runoff sub-basins

comparison for 50 subsamples showed slight differences (median of $3.3 \%$ difference).

Sub-samples were thawed for a few minutes then chl- $a$ was extracted by boiling a subsample of periphyton for two to three minutes in reagent grade methanol (Spectranalyzed ${ }^{\mathrm{TM}}$, Fisher Chemical $^{\mathrm{TM}}$ ) while being manually ground with a glass rod in a centrifuge tube. The subsample was then centrifuged to clarify the extract solution, transferred to the $4 \mathrm{~cm}$ spectrophotometer cell, and optical density was measured on a dual-beam Shimadzu UV-1700 series spectrophotometer at 653, 666, and $750 \mathrm{~nm}$. A methanol blank was used in the reference $4 \mathrm{~cm}$ cell. A wavelength of $750 \mathrm{~nm}$ was used to correct for turbidity. The amount of chl- $a$ was calculated applying the equation from Iwamura et al. (1970):

Chl- $a=17.12 *$ O.D. $666-8.68 *$ O.D. 653

where chl- $a$ is in $\mu \mathrm{g} / \mathrm{ml}$, O.D. 666 is the optical density at $666 \mathrm{~nm}$ and O.D.653 is the optical density at $653 \mathrm{~nm}$. Sample site chl- $a\left(\mathrm{mg} / \mathrm{m}^{2}\right)$ was determined 
by accounting for sampling area $\left(\mathrm{m}^{2}\right)$, extract volume $(\mathrm{ml})$ and total sample wet weight relative to subsample wet weight.

The wet weight was taken on the AFDM subsample (SWM). After drying in an oven at $60{ }^{\circ} \mathrm{C}$ for at least $10 \mathrm{~h}$, the subsample was weighed to provide a dry weight (SDM60), then combusted at $500{ }^{\circ} \mathrm{C}$ for an hour. After removal, the subsample was weighed again (SCM500). AFDM was calculated as:

$\operatorname{AFDM}\left(\mathrm{g} / \mathrm{m}^{2}\right)=(\mathrm{TWM} / \mathrm{SWM}) *(\mathrm{SDM} 60-\mathrm{SCM} 500) /$ area sampled $\left(\mathrm{m}^{2}\right)$

Less than 1 percent of data were censored based on several factors. Extremely high or low outliers among replicates were identified and censored when comparison with other replicate values at the time of collection and in the samplings prior to and following the sampling date indicated them as anomalous. Heavy sand content which contributed to high variation among replicates also led to censoring of a few replicates. Finally, where biomass was extremely heavy and possible drawing of material into the sampler from outer edges was suspected, these samples were also censored.

An "Autotrophic Index" (AI) was calculated as the ratio of AFDM $\left(\mathrm{mg} / \mathrm{m}^{2}\right)$ to chl- $a\left(\mathrm{mg} / \mathrm{m}^{2}\right)$ (Biggs \& Kilroy, 2000). A high AI indicated more organic material than chl- $a$ materials.

Algal percent cover was estimated at a depth of $0.5 \mathrm{~m}$ as an additional measure of biomass accrual. Predominant periphyton communities (i.e. stalked diatoms, filamentous green algae, and cyanobacteria) were noted while snorkeling. To verify the identification of predominant communities, a microscope was used to confirm the snorkel identification some of the time. In 2015 this laboratory confirmation became more standard and was conducted for roughly half of the monitoring events in order to permit training of new sampling staff. In these audits, the dominant group was usually found to be consistent with the snorkel identification, particularly when there was high biomass present. Lake level data were obtained from the United States Geological Survey station near Tahoe City (USGS, 2019).

Statistical methods

To assess monthly biomass, Kruskal-Wallis tests were performed followed by Dunn's test with $p$ adjusted using Bonferroni's method (Bonferroni, 1936; Kruskal \& Wallis, 1952; Dunn, 1964; Abdi, 2007). A Mann-Kendall test was used to evaluate monotonic trends within the time series data. Specifically, this method was used in place of parametric linear regression analysis because the test does not require that the trend be linear and it assumes independence between sampling events (Mann, 1945; Kendall, 1975). The test produces the Kendall's Tau which indicates the strengths of the variable's association; the S-statistic which compares each point's relation to the following points; the z-score which is the normalized test statistic; and the $P$-value which indicates the significance level. A positive S-statistic indicates an increasing trend while a negative value points to a decreasing trend. A $P$-value of 0.05 or smaller was considered a significant trend. Though 0.05 is the standard accepted $P$-value, some notable additional results with higher $P$-values were included in the tables for the reader's consideration of ecological significance. All statistical tests were performed with R (version 3.6.2, R Core Team, 2013). Mann-Kendall tests incorporated all data including outlier values because maximum values are viewed as important features of annual biomass cycles.

To analyze spatial data, all sites were grouped into north, south, east and west based on their location around the lake (Table 1). In addition, the level of human development associated with each of the sites was quantified using QGIS analysis. Runoff subbasins were delineated based on United States Geological Survey digital elevation model topography (Arundel et al., 2015). The sub-basin delineation was used to clip a raster layer containing land use information from the National Land Cover Database 2011 survey (MRLC, 2011). The resulting polygons were used to calculate percent impervious coverage for runoff sub-basins. While only $30 \%$ of the watershed area is considered impervious (or urban), approximately $67 \%$ of the nutrients are derived from this area (Sahoo et al., 2013). The 33rd and 67th percentiles were used to divide percent impervious cover data into the categories of low (0-9\% impervious cover), medium (10-19\% impervious cover), and high development (>19\% impervious cover) (Table1). Much of the Tahoe basin landcover is either housing developments or forest so this measure of urbanization encapsulated our land uses of interest. 
Data were separated into the time periods of years 1982 to 1993 and 2000 to 2019 to assess long-term historic versus variability over 20 years. The year 2000 was chosen as the break point because there was a change in the trend of lake clarity and phosphorus levels around that year (Tahoe Environmental Research Center, 2019). These changes suggest a shift in the overall lake ecosystem occurring around this time that could potentially affect periphyton. For the earlier 1982-1993 period, chl- $a$ data was available from 1982-1985 and 1989-1993 and trends from those times were analyzed together. For AFDM, data was available and analyzed for 1989-1993.

\section{Results}

Temporal variability and trends

Statistically significant temporal trends for data from all routine sites combined around the lake at $0.5 \mathrm{~m}$, were found for AFDM but not for chl- $a$ (Table 2). A Mann-Kendall test showed that there was no significant long-term trend in periphyton chl- $a$ when all sites data were combined during the entire period of record (1982-2019), or the more recent 2000-2019 period (Table 2). However, there was a negative lakewide trend $(P=0.01)$ in AFDM for all available years (1989-2019) and for the more recent period 2000-2019 $(P<0.01)$. Mann-Kendall tests based on the limited data from 1982 to 1993 showed increasing periphyton AFDM and chl- $a$ at $0.5 \mathrm{~m}$ (both $P<0.01)$. However, these results were based on an incomplete data set that did not include the period of 1982-1987 (Fig. 3). A Mann-Kendall test, run on the peak biomass, synoptic dataset, showed no significant trends at $0.5 \mathrm{~m}$.

Individual routine sites showed a mixture of statistically significant trends at $0.5 \mathrm{~m}$ for chl- $a$ and AFDM through time. There was a statistically significant increase in periphyton chl- $a$ at one site (Incline West) on the northwest shoreline (Table 2). Three other sites (Zephyr Pt., Dollar Pt., and Sugar Pine Pt.) showed statistically significant declines in chl- $a$. These sites are dispersed around the lake: Dollar Pt. is on the northwest shore, Zephyr Pt. is on the southeast shore, and Sugar Pine Pt. is along the southwest shore. Both Dollar Pt. and Zephyr Pt. are adjacent to developed areas. Sugar Pine Pt. is adjacent to a state park
(Table 1, Fig. 2). Five sites that ranged from low to high in levels of development (Deadman Pt., Incline Condo, Rubicon Pt., Sand Pt., and Zephyr Pt.) showed statistically significant $(P<0.05)$ declines in AFDM. The other sites showed no significant trend in AFDM over each of the periods of record analyzed.

Periphyton community biomass exhibited clear seasonal patterns (Fig. 4). Data from all routine monitoring sites show that median biomass as both AFDM and chl- $a$ tended to be lowest in summer (June through August) well after cessation of the spring snowmelt runoff, when water level was beginning to decline from summer high levels. Median AFDM and chl- $a$ levels generally were highest during spring (March-April) when the water level was typically rising associated with winter storm inputs, prior to or during onset of the spring snowmelt. Some chl$a$ observations were over $100 \mathrm{mg} / \mathrm{m}^{2}$ and as high as $254.7 \mathrm{mg} / \mathrm{m}^{2}$ in months of highest biomass while maximum observations where under $100 \mathrm{mg} / \mathrm{m}^{2}$ in the months of low biomass. Many AFDW observations were well over $100 \mathrm{~g} / \mathrm{m}^{2}$ in the months of highest biomass and as high as $219.8 \mathrm{~g} / \mathrm{m}^{2}$ while they were generally under $100 \mathrm{~g} / \mathrm{m}^{2}$ in the low biomass months. In the months of high median biomass, there was a high ratio of live photosynthetic material to detrital or stalk material in the mat. Thus, median AI was lower, reaching its lowest monthly median of 731 in March. AI reached its median monthly maximum of 1496 in September.

\section{Community variability and trends}

Epilithic periphyton communities, which were classified by the dominant taxonomic division(s) visible in the periphyton mat, showed patterns over time and space. The frequency that a community was observed was calculated from the routine data as a ratio of the times a community was observed each year to the total number of yearly observations. Each year, either stalked diatoms or cyanobacteria were most frequent and there were no years where filamentous green algae were the most frequent (Fig. 5). The water level cycles influenced the type of periphyton community. Cyanobacteria were primarily found at $0.5 \mathrm{~m}$ when lake levels were stable or declining while diatoms mostly dominated when lake levels increased (Fig. 5). Additionally, cyanobacteria mostly dominated in the 15 years with low water level while stalked diatoms 
Table 2 Mann-Kendall Test Results for Lake Tahoe AFDM and chl- $a$

\begin{tabular}{|c|c|c|c|c|c|c|c|}
\hline Location & Dominant community & Years & Constituent & Tau & $\mathrm{S}$ & $z$ & $P$ \\
\hline \multirow[t]{10}{*}{ Lake-wide } & All & 1982-2019 & Chl- $a$ & -0.02 & -2586 & -1.34 & 0.18 \\
\hline & All & 1982-1993 & Chl- $a$ & .34 & 3856 & 10.07 & $<0.01 * *$ \\
\hline & All & 2000-2019 & Chl- $a$ & -0.03 & -1416 & -1.29 & 0.2 \\
\hline & All & 1989-2019 & AFDM & -0.16 & -8439 & -7.4 & $<0.01 * *$ \\
\hline & All & 1989-1993 & AFDM & 0.24 & 434 & 4.13 & $<0.01 * *$ \\
\hline & All & 2000-2019 & AFDM & -0.06 & -2231 & -2.58 & $0.01 * *$ \\
\hline & Cyanobacteria & 1989-2019 & AFDM & -0.19 & -0.19 & -3.19 & $<0.01 * *$ \\
\hline & Cyanobacteria & 1989-2019 & Chl- $a$ & -0.09 & -877 & -2.06 & $0.04 *$ \\
\hline & Diatoms & 1989-2019 & AFDM & 0.01 & 46 & 0.19 & 0.85 \\
\hline & Diatoms & 1989-2019 & Chl- $a$ & -0.03 & -148 & -0.6 & 0.55 \\
\hline \multirow[t]{2}{*}{ Deadman Pt } & All & 1989-2019 & AFDM & -0.28 & -1776 & -4.41 & $<0.01 * *$ \\
\hline & Cyanobacteria & 1989-2019 & AFDM & -0.29 & -165 & -2.43 & $0.02 *$ \\
\hline \multirow[t]{3}{*}{ Dollar Pt } & All & 1982-2019 & Chl- $a$ & -0.13 & -1747 & -2.51 & $0.01 * *$ \\
\hline & Cyanobacteria & 1989-2019 & Chl- $a$ & -0.26 & -340 & -2.68 & $0.01 * *$ \\
\hline & Cyanobacteria & 1989-2019 & AFDM & -0.28 & -129 & -2.18 & $0.03 *$ \\
\hline \multirow[t]{3}{*}{ Incline West } & All & 1982-2019 & Chl- $a$ & 0.28 & 2665 & 4.85 & $<0.01 * *$ \\
\hline & Cyanobacteria & 1989-2019 & Chl- $a$ & 0.24 & 277 & 2.38 & $0.02 *$ \\
\hline & Diatoms & 1989-2019 & AFDM & -0.51 & -40 & -2.38 & $0.02 *$ \\
\hline Sugar Pine Pt & All & 1982-2019 & Chl- $a$ & -0.19 & -1461 & -3.15 & $<0.01 * *$ \\
\hline Rubicon Pt & All & 1989-2019 & AFDM & -0.16 & -1034 & -2.53 & $0.01 * *$ \\
\hline Sand Pt & All & 1989-2019 & AFDM & -0.29 & -1966 & -4.69 & $<0.01 * *$ \\
\hline \multirow[t]{3}{*}{ Zephyr Pt } & All & 1982-2019 & Chl- $a$ & -0.19 & -2491 & -3.54 & $<0.01 * *$ \\
\hline & All & 1989-2019 & AFDM & -0.37 & -2668 & -6.05 & $<0.01 * *$ \\
\hline & Cyanobacteria & 1989-2019 & AFDM & -0.33 & -164 & -2.64 & $0.01 * *$ \\
\hline
\end{tabular}

In some cases, all available sampling was tested, in others only data from cyanobacteria or diatom dominated water years were tested. Data from 1986-1988 and 1994-1999 were not collected. Significant and interesting not significant results were included for the lakewide tests, while only the significant individual site results were included. Note that $P$-values denoted with $* *$ are significant to the 0.01 level and those denoted with $*$ are significant to the 0.05 level

dominated in the eight years with high waters (Fig. 5). As lake level fluctuated, the bottom substrate either became exposed and desiccated as lake level dropped, or conversely, previously exposed rock was submerged as the lake rose. At a few sites such as Pineland and Tahoe City, stalked diatoms might still be dominant in what were otherwise characterized as cyanobacteria dominated years (based on lake-wide characterization of dominant algae at $0.5 \mathrm{~m}$ ). A prevalence of cyanobacteria at east shore sites and some sites along west and north shores may account for the cyanobacteria dominance in "cyanobacteria dominant" years.

Summary statistics for chl- $a$ and AFDM levels at $0.5 \mathrm{~m}$ varied in years when stalked diatoms dominated compared with years when cyanobacteria dominated. In years in which stalked diatoms dominated, chl$a\left(\mathrm{Q} 1=6.7 \mathrm{mg} / \mathrm{m}^{2}\right.$, median $=13.6 \mathrm{mg} / \mathrm{m}^{2}, \max =$ $\left.241.8 \mathrm{mg} / \mathrm{m}^{2}\right)$ was significantly different $(P<0.01)$ compared with years when cyanobacteria were most abundant $\left(\mathrm{Q} 1=11.2 \mathrm{mg} / \mathrm{m}^{2}\right.$, median $=19.2 \mathrm{mg} / \mathrm{m}^{2}$, $\left.\max =254.7 \mathrm{mg} / \mathrm{m}^{2}\right)$. Similarly, years where stalked diatoms dominated had significantly lower $(P<0.01)$ $\operatorname{AFDM}\left(\mathrm{Q} 1=4.5 \mathrm{~g} / \mathrm{m}^{2}\right.$, median $=10.7 \mathrm{~g} / \mathrm{m}^{2}, \max =$ $\left.203.9 \mathrm{~g} / \mathrm{m}^{2}\right)$ than years where cyanobacteria dominated $\left(\mathrm{Q} 1=13.8 \mathrm{~g} / \mathrm{m}^{2}\right.$, median $=26.2 \mathrm{~g} / \mathrm{m}^{2}, \max =$ $163.9 \mathrm{~g} / \mathrm{m}^{2}$ ). Maximum values and standard deviations showed that stalked diatom-dominated years had larger ranges of biomass. The AI calculated for observations in which only a single community was 

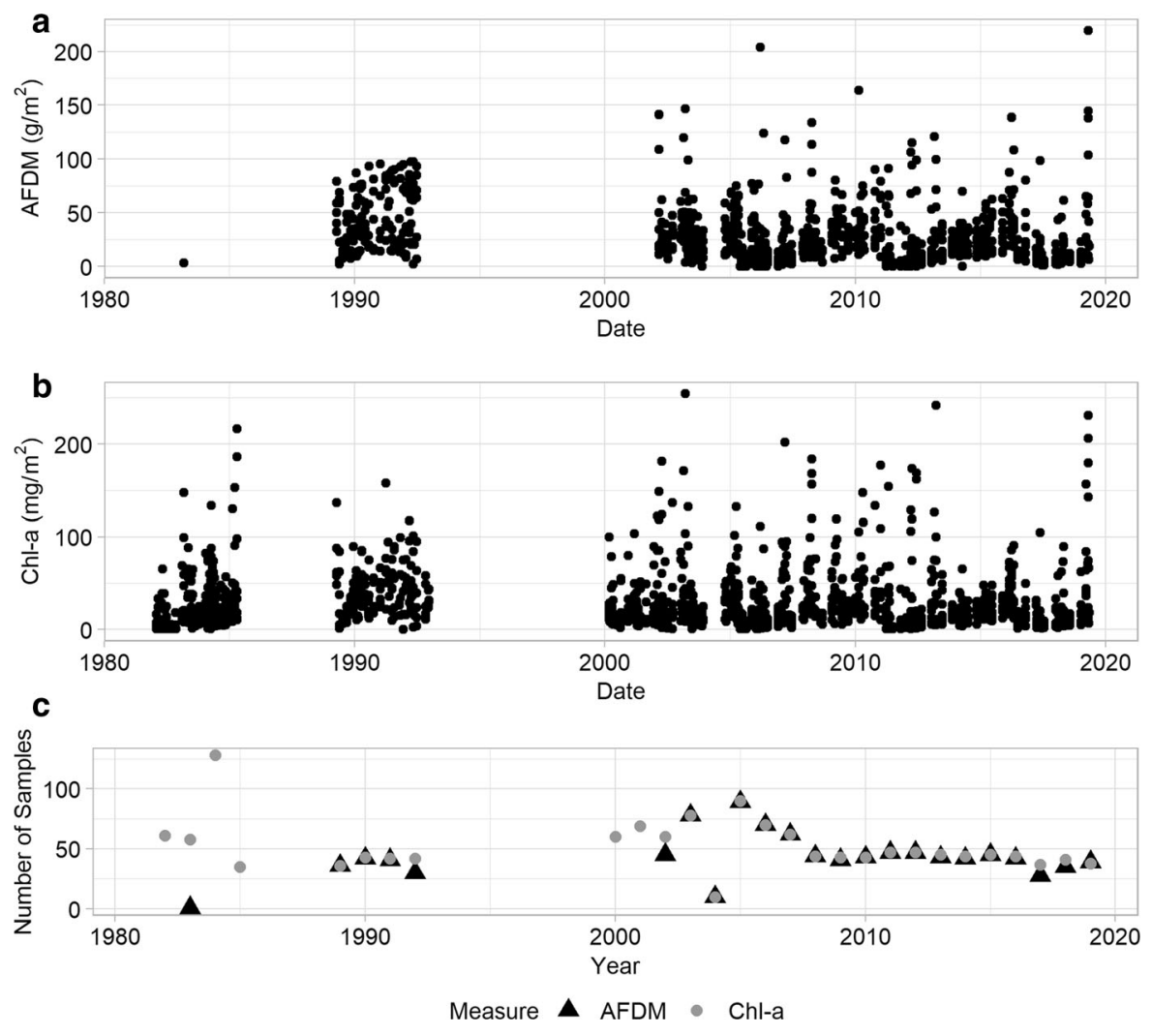

Fig. 3 Routine site periphyton a AFDM, b chl- $a \mathbf{c}$ and instances of AFDM and chl- $a$ measurement per year at $0.5 \mathrm{~m}$. Instances per year sometimes coinside for AFDM and chl- $a$. There are large data gaps in the first 20 years of the dataset

visually observed showed that stalked diatoms and filamentous green algae had a median ratio of 731 $(\mathrm{Q} 1=518, \max =7277)$, and $865(\mathrm{Q} 1=485, \max =$ 7084), respectively, whereas cyanobacteria had a higher median ratio of $1248(\mathrm{Q} 1=961$, $\max =2662)$.

At each site, the maximum chl- $a$ concentration was higher in cyanobacteria dominated years than in stalked diatom dominated years, though sometimes by a small amount (Table 3). Similarly, at all sites but Pineland, median chl- $a$ was higher in cyanobacteria dominated years than in stalked diatom dominated years. These patterns of higher maximum and median values in cyanobacteria dominated years held true in the AFDM measurements at all sites with the exceptions of Dollar Pt. which had lower maximums and means on cyanobacteria dominated years and Tahoe City and Pineland which had lower maximums in cyanobacteria dominated years. To identify trends specifically within the stalked diatom and filamentous green algal communities, which tended to be spatially intermixed, the Mann-Kendall trend test was also conducted on data for Water Years (October 1 to September 30) in which diatoms dominated in field identifications. Data from 1982 to 1988 were not included in this analysis since there was limited or no information on predominant algal types for this period. The results indicated that for years when diatoms were predominant, generally in higher lake level years, there was no significant lake-wide trend in algal biomass over time for either AFDM or chl- $a$ (Table 2). When the data for individual sites were examined, only one routine site (Incline West) showed a significant trend and this was for AFDM (Table 2). This site showed a decreasing trend. No significant trends were found for chl- $a$ at individual sites.

Where cyanobacteria dominated the community observations, generally in lower lake level years, a Mann-Kendall test showed temporal trends towards decreasing biomass. The results of the test for these data showed a significant decrease lake-wide in AFDM and chl- $a$ (Table 2). The results for individual sites using this analysis showed Dollar Pt. had a 


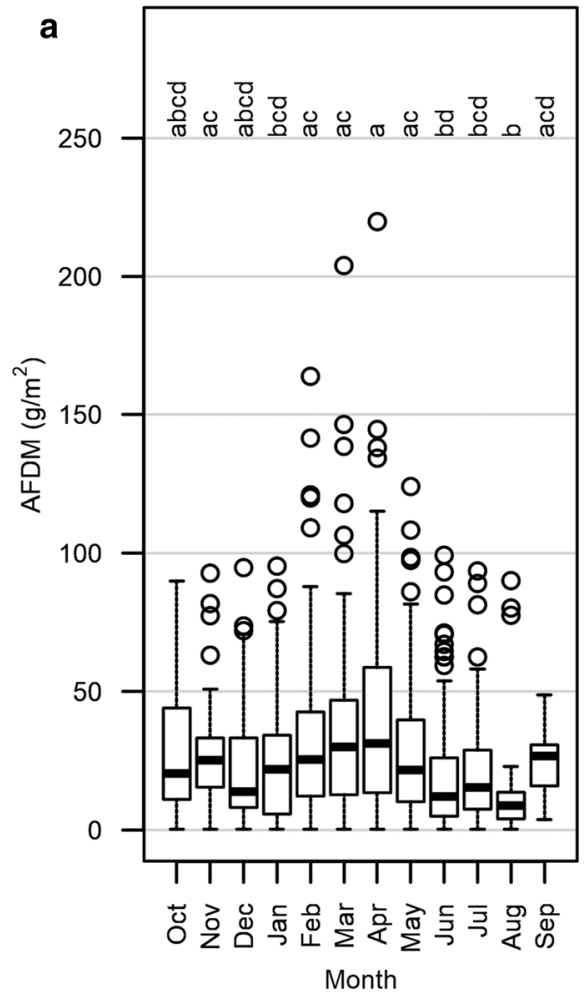

Fig. 4 Periphyton monthly biomass variability from 1982 to 2019 for a AFDM and b chl- $a$. The boxes represent the monthly interquartile range and the thick center lines represent the median. Whiskers represent 1.5 times the Interquartile range or if no data exceeds that value the whisker are the maximum or minimum. The circles indicate outliers that are defined by standard convention as outside of the whiskers. Different letters

significant decreasing chl- $a$ trend over time and Incline West had a significant increasing trend. Deadman Pt., Dollar Pt., and Zephyr Pt. had significant decreasing AFDM trends over time (Table 2).

Spatial variability and trends

Routine site data showed that there was great variation between sites (Table 3). Sites such as Pineland had high levels of periphyton by every summary statistic while sites like Zephyr Pt. and Sugar Pine had relatively low amounts of periphyton.

The spring synoptic surveys showed that, sites on the eastern side of the lake tended to have lower annual peak biomass (Table 4). The highest peak biomass was in the northern and western parts of the lake with the highest found at the Tahoe City Public Utility District Boat Ramp, Ward Creek, Garwoods, Gold Coast, and

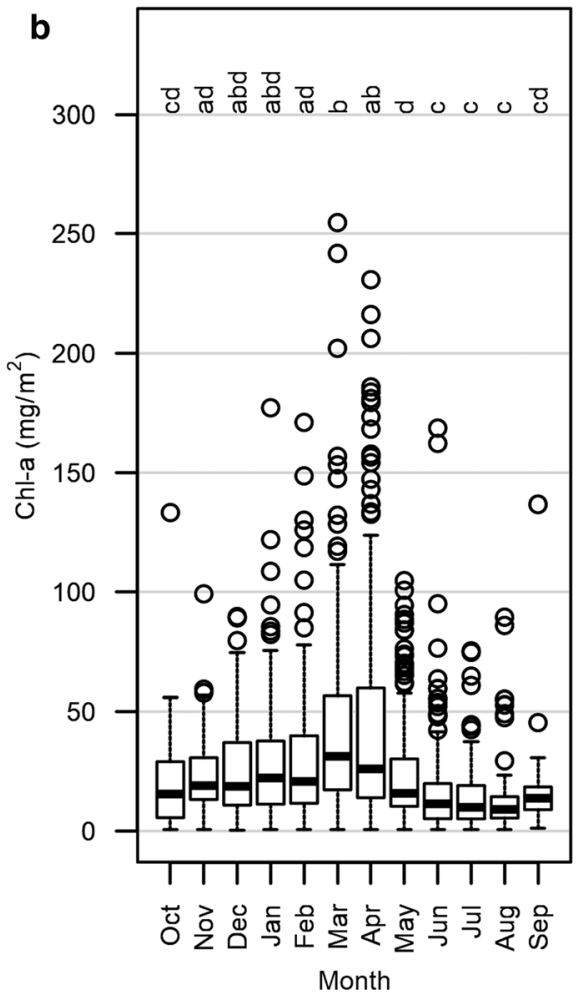

above each box represent significant differences between months at the 0.05 level using Dunn's test for multiple pair wise comparison. Months with the same letter above them are not significantly different from each other while months with different letters above them are significantly different from one another

Tahoe City Tributary sites (Fig. 6). Around the lake, the largest chl- $a$ biomasses recorded were predominantly associated with stalked diatoms and filamentous green algae.

The northern region had the highest median algal percent coverages for spring synoptic sites. Individual sites with the highest percent coverage included Kaspian Pt., Lake Forest, E. Bay/Rubicon, Tahoe City Tributary, and Ward Creek.

\section{Discussion}

Temporal variability and trends

Over the last three decades, periphyton biomass at $0.5 \mathrm{~m}$ has not significantly changed lake-wide; however, a significant decline was observed at several 

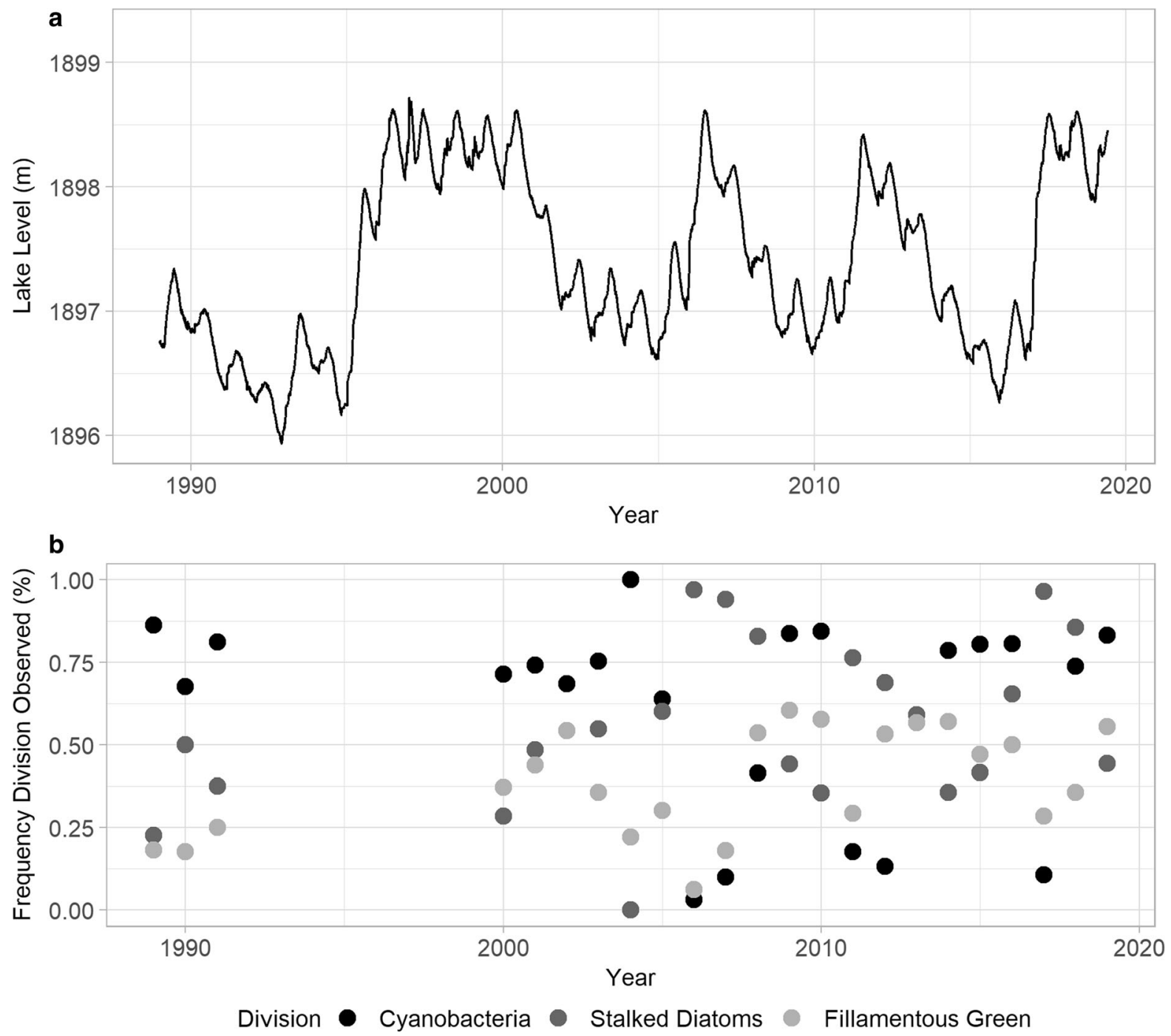

Fig. 5 Lake level change effected what communities were observed at $0.5 \mathrm{~m}$. Plot a shows a lake level change over time and $\mathbf{b}$ shows annual percentage of the time that each periphyton community was observed

sites. Lake-wide, chl- $a$ showed no trend, while AFDM declined. We attribute these divergent trends in the indices of periphyton biomass to the fact that AFDM measures live and detrital organic matter within the periphyton mat from the entire benthic community and can accumulate over multiple years, while chl- $a$ pigment degrades and sloughs off the substrate after senescence. Further, the long strands that are found in the stalked diatom community are not pigmented as the stalks are composed of carbohydrates (Kilroy \& Bothwell, 2014). This may indicate that the divergent trends since 2000 are due to a change in species composition. The increasing trend found in data from
1982 to 1993 is based on incomplete data but chl-a was higher in 1993 than in 1982.

When compared to other oligotrophic lakes with periphyton blooms, Lake Tahoe's periphyton biomass at $0.5 \mathrm{~m}$ depth falls on the low end of the reported range. For example, Lake Taupo in New Zealand regularly produces periphyton chl- $a$ biomasses over $500 \mathrm{mg} / \mathrm{m}^{2}$ and has recorded values over $1500 \mathrm{mg} / \mathrm{m}^{2}$ between 0 and $2 \mathrm{~m}$ depth (Hawes \& Smith, 1994). Other lakes, such as Lake Chelan, have biomass levels more comparable to Lake Tahoe's biomass at $0.5 \mathrm{~m}$ with periphyton chl- $a$ biomass reaching $140 \mathrm{mg} / \mathrm{m}^{2}$ at 2 m depth (Jacoby et al., 1991). 
Table 3 Biomass summary statistics of routine periphyton sites for all years combined, years where community was documented and cyanobacteria were most frequently observed, and years where community was documented and stalked diatoms where most frequently observed for (a) AFDW and (b) chl- $a$

\begin{tabular}{|c|c|c|c|c|c|c|c|c|c|}
\hline \multicolumn{10}{|c|}{ (a) $\operatorname{AFDM}\left(\mathrm{g} / \mathrm{m}^{2}\right)$} \\
\hline \multirow[t]{2}{*}{ Site } & \multicolumn{3}{|c|}{ All years } & \multicolumn{3}{|c|}{ Cyanobacteria dominated years } & \multicolumn{3}{|c|}{ Stalked diatom dominated years } \\
\hline & Q1 & Median & Max & Q1 & Median & Max & Q1 & Median & Max \\
\hline Deadman Pt & 8.98 & 28.99 & 97.33 & 26.71 & 39.00 & 95.32 & 0.08 & 6.35 & 26.48 \\
\hline Dollar Pt & 10.90 & 18.42 & 134.25 & 13.01 & 18.49 & 109.20 & 8.08 & 19.51 & 134.25 \\
\hline Incline Condo & 7.44 & 19.38 & 70.7 & 21.08 & 31.74 & 70.70 & 4.05 & 7.81 & 17.25 \\
\hline Incline West & 8.67 & 27.29 & 108.36 & 23.30 & 34.35 & 108.36 & 6.03 & 8.59 & 66.09 \\
\hline Pineland & 14.39 & 28.05 & 219.77 & 14.68 & 28.59 & 99.85 & 12.30 & 24.90 & 115.14 \\
\hline Rubicon Pt & 12.47 & 25.49 & 144.67 & 17.60 & 27.14 & 144.67 & 4.71 & 8.36 & 113.79 \\
\hline Sand Pt & 6.33 & 29.71 & 97.42 & 20.59 & 32.96 & 93.59 & 1.02 & 4.24 & 34.81 \\
\hline Sugar Pine Pt & 2.70 & 8.38 & 70.9 & 7.02 & 14.24 & 70.90 & 1.68 & 3.36 & 18.83 \\
\hline Tahoe City & 15.46 & 33.57 & 203.86 & 16.49 & 33.64 & 163.90 & 14.65 & 33.57 & 203.86 \\
\hline Zephyr Pt & 8.55 & 15.06 & 59.2 & 12.30 & 18.21 & 59.20 & 3.40 & 8.09 & 31.91 \\
\hline \multicolumn{10}{|c|}{ (b) Chl- $a\left(\mathrm{mg} / \mathrm{m}^{2}\right)$} \\
\hline \multirow[t]{2}{*}{ Site } & \multicolumn{3}{|c|}{ All years } & \multicolumn{3}{|c|}{ Cyanobacteria dominated years } & \multicolumn{3}{|c|}{ Stalked diatom dominated years } \\
\hline & Q1 & Median & Max & Q1 & Median & Max & Q1 & Median & Max \\
\hline Deadman $\mathrm{Pt}$ & 5.75 & 14.88 & 66.92 & 14.24 & 24.30 & 66.92 & 2.95 & 6.94 & 22.58 \\
\hline Dollar Pt & 12.54 & 24.07 & 157.71 & 12.52 & 25.35 & 157.71 & 10.48 & 19.90 & 156.52 \\
\hline Incline Condo & 9.14 & 15.03 & 98.93 & 8.89 & 13.66 & 67.94 & 7.30 & 12.80 & 31.90 \\
\hline Incline West & 8.93 & 15.18 & 69.59 & 13.26 & 19.28 & 69.59 & 7.61 & 13.94 & 62.46 \\
\hline Pineland & 15.27 & 31.96 & 241.77 & 16.53 & 32.14 & 241.77 & 9.72 & 49.57 & 241.77 \\
\hline Rubicon Pt & 9.62 & 19.51 & 216.28 & 14.82 & 21.98 & 179.37 & 4.20 & 14.19 & 168.62 \\
\hline Sand Pt & 6.08 & 13.90 & 100.74 & 10.57 & 19.24 & 99.24 & 2.62 & 6.22 & 40.24 \\
\hline Sugar Pine Pt & 5.15 & 11.20 & 130.14 & 5.48 & 10.83 & 66.35 & 2.44 & 6.57 & 37.18 \\
\hline Tahoe City & 16.49 & 32.05 & 254.68 & 16.14 & 32.12 & 254.68 & 18.03 & 31.68 & 202.09 \\
\hline Zephyr Pt & 9.89 & 14.50 & 87.42 & 10.91 & 14.14 & 87.42 & 6.67 & 9.88 & 76.45 \\
\hline
\end{tabular}

Table 4 Periphyton abundance metrics including median, first quartile (Q1), and the number of sites from 2003 to 2019 synoptic surveys by geographical region

\begin{tabular}{llll}
\hline Region & AFDM \pm Q1 (\# sites) $\left(\mathrm{g} / \mathrm{m}^{2}\right)$ & Chl- $a \pm \mathrm{Q} 1(\#$ sites $)\left(\mathrm{mg} / \mathrm{m}^{2}\right)$ & $\%$ Cover \pm Q1 (\# sites) \\
\hline North & $30.84 \pm 15.46(19)$ & $34.13 \pm 13.94(19)$ & $70 \pm 60(20)$ \\
East & $12.00 \pm 6.27(16)$ & $13.32 \pm 7.33(16)$ & $70 \pm 50(19)$ \\
South & $14.05 \pm 5.16(5)$ & $21.13 \pm 7.05(5)$ & $60 \pm 40(5)$ \\
West & $29.61 \pm 9.27(13)$ & $37.97 \pm 11.75(13)$ & $75 \pm 60(14)$ \\
\hline
\end{tabular}



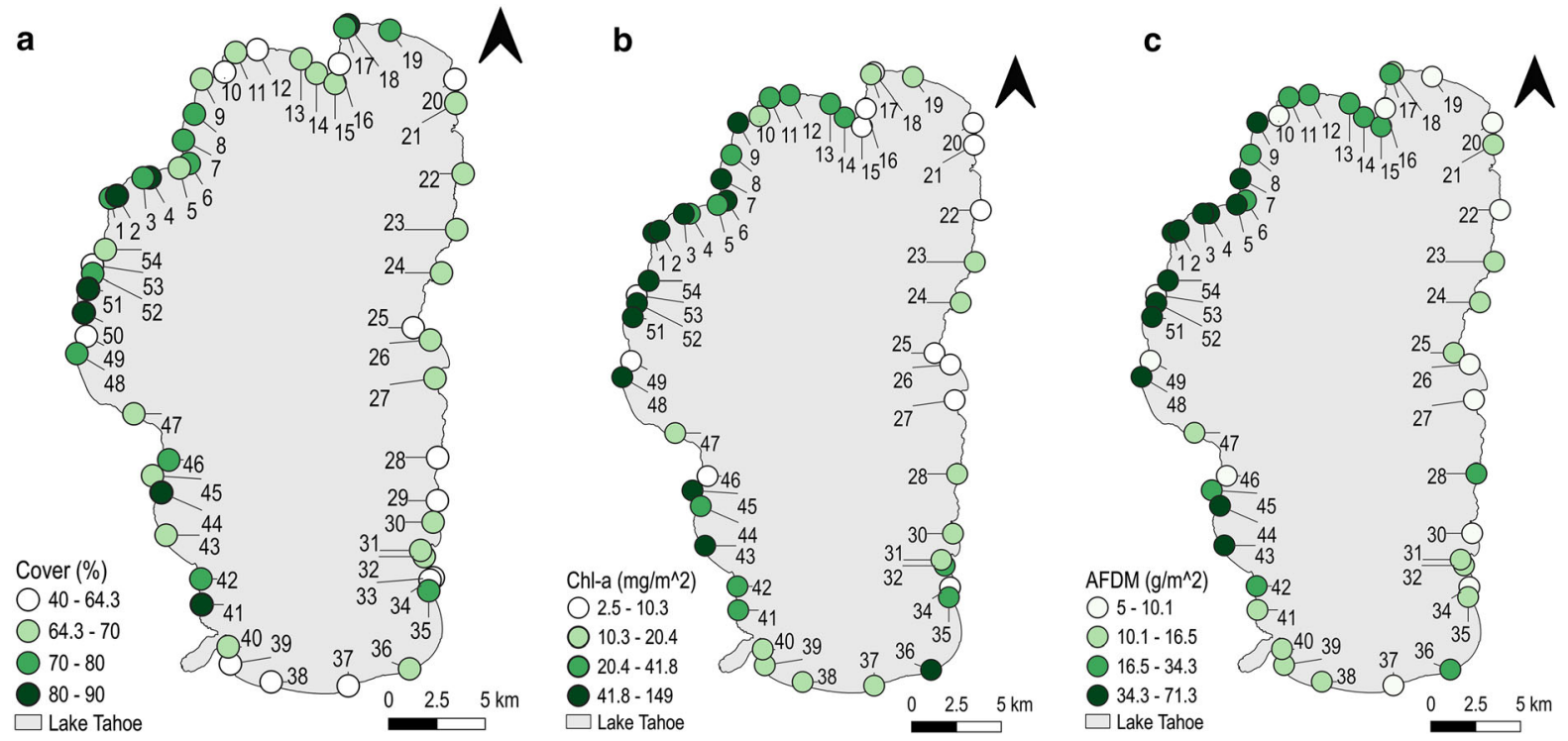

Fig. 6 Map of median a percent cover, b chl-a, and $\mathbf{c}$ AFDM at all sites. Marker color represents quantile ranges. All biomass measures are higher on the north and west sides of the lake as compared to the south and east sides of the lake

Changes relevant to periphyton biomass may have begun prior to our monitoring. The Signal Crayfish [Pacifastacus leniusculus (Dana, 1852)] was introduced in the 1930s and 1940s. These crayfish graze on the periphyton and excrete nutrients in a more bioavailable form which may contribute to growth of the periphyton (Flint \& Goldman, 1975). Anthropogenic impacts associated with rapid development of the Tahoe basin occurred in the 1950s and 1960s. Periphyton were noticed to be visibly higher in the spring of 1967 compared to the late 1950s (Goldman, 1967). Shortly after these observations, the Tahoe Research Group began monitoring of periphyton (Goldman, 1974), however, the monitoring focused on the use of artificial substrates suspended above the bottom and results were not directly comparable with later monitoring of periphyton on rocks in the nearshore. Their results showed that chlorophytes and diatoms dominated the periphyton species with low species diversity. They also found periphyton growth rates were highest near the stream mouths and primary production ranged from $0.343 \mathrm{mg} \mathrm{C} / \mathrm{m}^{2} /$ day in the south of the lake to $1.010 \mathrm{mg} \mathrm{C} / \mathrm{m}^{2} /$ day in the northeast. Limited anecdotal and photographic evidence suggest there was likely less periphyton along the shoreline before the period of rapid population growth and development in the 1950s and 1960s (TERC, unpublished). Many Tahoe developments were on septic systems prior to the 1970s. All residences were on sewer lines by the early 1970s, and all sewage was exported from the basin. This could have reduced problems associated with overloaded septic systems during storms and eventually resulted in less nutrient inputs to the lake. However, it is unknown how long septic system nutrients affected the quality of the natural subsurface groundwater flow entering the lake or if this septic plug still effects water quality today.

There were no clear patterns linking temporal biomass trends with levels of development. Two of the sites with decreasing chl- $a$ were adjacent to areas of high development (Zephyr Pt. and Dollar Pt.) while one (Sugar Pine Pt.) was near an area of low development. Five of the sites, near areas with levels of development ranging from low to high, showed a decrease in AFDM. One of the sites, Zephyr Pt., showed a decrease in both chl- $a$ and AFDM despite being in a high development sub-basin. These findings suggest that our measure of development level alone does not explain temporal trends in algal biomass and may not have a direct relationship with nutrients, which are likely an important influence in periphyton biomass. Thus, other influences, such as additional sources of nutrients must be considered. Decreases in periphyton at some developed areas may be the result of watershed remediation projects designed to 
decrease erosion and associated nutrients from entering the lake. Data on site specific reductions are lacking so direct correlations cannot be made.

Periphyton biomass at $0.5 \mathrm{~m}$ shows a clear seasonal pattern with increases as early as December in some years lasting through April, as water levels rise. The highest values during the period of record were typically found in March and April. This signals that peak accumulation occurs in the early spring between December and April. The spring peak in biomass may be due to a combination of factors. In winter, water levels rise as high runoff from storms and early snowmelt contributes both surface and subsurface discharge of nutrients into the lake (Leonard, 1979; Naranjo, 2019). Increases of solar radiation provide more light for photosynthesis. Lake mixing contributes nutrients to surface waters in late winter. Although the development of the periphyton mat can vary with the predominant community, observations suggest that in months of high biomass much of the live material in thick stalked diatom mats resides in the upper portion of the mat (attached to tips of stalks), while the basal-layer of the mat is senescent due to reduced irradiance resulting in weaker attachment to the substrate (Johnson et al., 1997; Clark et al., 2004). Photosynthetic oxygen bubbles produced in the upper portion of the mat lift the periphyton, increasing waveinduced shear and making the periphyton more susceptible to sloughing (Biggs \& Thomsen, 1995). The rate of periphyton growth may also decline later in the spring as lake level begins to near its maximum. In months of low biomass, much of the biomass is nonphotosynthetic senescent material, increasing AI.

Biomass trends in periphyton communities

There are currently two dominant periphyton communities in Lake Tahoe, unchanged from the 1980s. One community comprises filamentous green algae [such as Mougeotia genuflexa (Dillwyn) C. Agardh and Ulothrix zonata (Weber et Mohr) Kützing] and stalked diatoms [such as Gomphonema parvulum (Kützing) Kützing and Gomphoneis herculeana (Ehrenberg) Cleve] and shows no significant upward or downward temporal trend in biomass. Though there is interannual variation, it grows and colonizes quickly and is often found in the eulittoral zone (Reuter et al., 1986a, b). The second community, predominantly cyanobacteria, such as Calothrix scopulorum (Weber \& Mohr) C. Agardh and Nostoc entophytum Bornet \& Flahault, shows a decline in biomass over time. These cyanobacteria take longer to accumulate biomass and typically grow deeper, in the sublittoral zone (Loeb, 1980). Cyanobacteria dominated mats are primarily observed at our $0.5 \mathrm{~m}$ deep sampling sites during times of rapid lake level decline, such as the three drought periods within our dataset. Much of the reduction in biomass over time appeared to occur in water years when cyanobacteria dominated community observations, the years that also had the highest biomass measurements. In contrast, the stalked diatom and filamentous green algae dominated water years did not show statistically significant reductions in biomass over time. This may be related to the impact of repeated low water levels from the 1990s to the 2010s exposing and causing senesence in once stable cyanobacterial mats. The observed changes could be due solely to the position of lake level because of droughts rather than actual changes in community biomass. In addition, the rate of runoff and therefore position of the $0.5 \mathrm{~m}$ level can change rapidly or slowly depending on runoff patterns. A high runoff rate could result in a low periphyton biomass at $0.5 \mathrm{~m}$.

All three AI ratios are high relative to ratios found in many periphyton communities. For example, Rosenberger et al. (2008) measured three deep oligotrophic lakes in the USA with mean AIs ranging from 2 to 151 . Our high AI values agree with those found in other Lake Tahoe periphyton studies (Naranjo et al., 2019) and are likely due to the predominant type of algae present in Lake Tahoe's periphyton. To overcome shading by neighbors, the stalked diatom, Gomphoneis herculeana secretes stalks of extracellular polymeric substance that can constitute much of their biomass (Hoagland et al., 1993; Bothwell \& Kilroy, 2011). Therefore, the relatively high AI ratios found in cyanobacteria and stalked diatoms could be a combination of high AI values in the live community and indicative of a buildup of senescent mat material (Weitzel, 1979). We do not believe the high ratios necessarily indicate impacts of organic matter pollution, as has been shown in other systems (e.g. Collins \& Webber, 1978).

Spatial variability and trends

Based on our data, the southern and eastern sides of Lake Tahoe experience lower peak chl- $a$ and AFDW biomass on average than the north or west sides of the 
lake. Various studies have shown the importance of groundwater inflow on periphyton growth in Lake Tahoe (e.g. Loeb, 1987; Naranjo et al., 2019). A basinwide evaluation of nitrogen and phosphorus shows lower nutrient load for the east and south shores (USACE, 2003). The changing water table depth can affect the groundwater inflow of nutrients to the lake. Tahoe groundwater nutrient data are limited but these inflows may be responsible for much of the periphyton biomass variability including the high temporal and spatial heterogeneity in periphyton (Naranjo et al., 2019).

In addition to groundwater, multiple factors could contribute to this pattern. In addition to nutrient loads on the east side, southwesterly winds mean that the east side of the lake is more prone to a higher wave climate and wind-induced currents, which could induce the removal of algae by sloughing (Roberts et al., 2019). Constant abrasion from and movement of predominately mobile sandy substrate in the southern portion of the lake does not allow for a buildup of epilithic periphyton. This wind also causes water movement, leading to higher availability of nutrients and increased periphyton nutrient uptake (Reuter et al., 1986a, b).

Further factors contributing to observed trends

Many factors likely affect the observed periphyton spatiotemporal patterns for biomass, although limited explanatory data accompany our periphyton monitoring program. Stormwater can deliver water with high nutrient concentrations. Monitoring of stream discharge, sediment and nutrient concentrations and loading has been conducted on multiple streams in the Lake Tahoe basin since the early 1980s. Streamflow inflow can influence periphyton growth near the mouths of some streams while a more generalized impact of stream inputs of nutrients may be tempered by the fact that stream inflows are cold relative to the lake, so their nutrients often plunge deeper down the steep shoreline rather than move toward our $0.5 \mathrm{~m}$ sites along shore.

Nutrient inputs from surface and subsurface (groundwater) discharge, proximity to anthropogenic sources of nutrients and development, lake mixing and upwelling, lake-level changes, grazing, and exposure to waves may all contribute to observed biomass levels. Changes to these factors in Lake Tahoe since long-term monitoring began in the 1980s may have contributed to variability in periphyton growth. Compared to the 40 years before our study, the study period had highly variable lake levels (TERC, 2019). From the 1980 s to the 2020 s several periods of drought caused lower lake levels, as well as prolonged periods of stratification with reduced mixing-derived nutrient movement. Lake temperature has increased (TERC, 2019) and lake clarity was declining in the 1980s and 1990s and then began to level off in the 2000s. Since the 1980s, pelagic photic zone phosphorous has declined and nitrogen has increased, making Tahoe algae co-limited by these nutrients (Goldman et al., 1993). Mid-lake primary productivity more than quadrupled since 1970 (TERC, 2019). Additionally, stringent environmental regulations have helped to reduce inputs of sediments and nutrients associated with surface runoff. A combination of these factors could contribute to the reduction in periphyton AFDM seen at many sites around the lake.

\section{Conclusion}

Statistically significant trends at $0.5 \mathrm{~m}$ depth from all sites combined around the lake were absent for chl- $a$, but a trend of decreasing AFDM was found. Monitoring of periphyton at Lake Tahoe began after significant changes had been made to the watershed in the 1960s. It is possible that the primary period of change in periphyton biomass was associated with the environmental shifts during this period, however, no comparable monitoring data is available from this period or the years preceding it.

Data showed that periphyton at the $0.5 \mathrm{~m}$ depth was affected by seasonality and lake level. The periphyton biomass was highest in spring and lowest in summer. Periphyton community and biomass was affected by lake level changes. At $0.5 \mathrm{~m}$, cyanobacteria mostly dominated low water level years with while stalked diatoms dominated high water level years. Biomass was significantly higher when cyanobacteria dominated than when stalked diatoms dominated the observed community. Somewhat surprisingly, periphyton biomass was not correlated with level of development adjacent to the sites.

In the specific case described here, where a longterm dataset was collected in a consistent fashion over a 37-year span, our conclusions are limited by the 
nature of the sampling protocol adopted and maintained. With the benefit of hindsight, far more could have been learned if sampling had taken place in stationary positions in both the eulittoral and sublittoral zones and if community dynamics had been more consistently monitored. However, that would have required more time and resources than were available. Given limited monitoring budgets, technologies such as remote sensing may allow new opportunities in the future.

Periphyton blooms are occurring in oligotrophic lakes across the globe, and it is difficult to prove whether these blooms are changing due to a dearth of long-term monitoring data. To prove a change in the periphyton biomass, monitoring programs must begin data collection early and choose their monitoring design carefully, with an emphasis on the nearshore environment. Documenting conditions before and after periphyton blooms begin may be crucial for understanding the underlying causes of periphyton blooms in oligotrophic lakes and creating protocols to control future blooms.

Acknowledgements Many individuals have participated in the monitoring of this long and unique periphyton data set at Lake Tahoe over the last 30-40 years and their collective contributions are recognized. Stanford Loeb initiated the synoptic monitoring program and Jane Aloi was a key researcher as the program began. Our current sampling team members include Katie Senft and Brandon Berry. This study was financially supported by the David and Dana Loury Foundation, the Boyd Foundation, and the University of California, Davis. Funding for the collection and analysis of the long-term periphyton data set was supported by various resource agencies in the Tahoe basin, most notably the Lahontan Regional Water Quality Control Board and the Tahoe Regional Planning Agency.

Open Access This article is licensed under a Creative Commons Attribution 4.0 International License, which permits use, sharing, adaptation, distribution and reproduction in any medium or format, as long as you give appropriate credit to the original author(s) and the source, provide a link to the Creative Commons licence, and indicate if changes were made. The images or other third party material in this article are included in the article's Creative Commons licence, unless indicated otherwise in a credit line to the material. If material is not included in the article's Creative Commons licence and your intended use is not permitted by statutory regulation or exceeds the permitted use, you will need to obtain permission directly from the copyright holder. To view a copy of this licence, visit http://creativecommons.org/licenses/by/4.0/.

\section{References}

Abdi, H., 2007. Bonferroni and Sidák Corrections for Multiple Comparisons. Encyclopedia of Measurement and Statistics, 3rd ed, 103-107.

Aloi, J. E., 1986. The Ecology and Primary Productivity of the Eulittoral Epilithon Community: Lake Tahoe, CaliforniaNevada. University of California, Davis, Davis.

Aloi, J. E., S. L. Loeb \& C. R. Goldman, 1988. Temporal and spatial variability of the eulittoral epilithic periphyton, Lake Tahoe, California-Nevada. Journal of Freshwater Ecology 4: 401-410.

Arundel, S. T., C. M. Archuleta, L. A. Phillips, B. L. Roche \& E. W. Constance, 2015. 1-Meter Digital Elevation Model Specification: U.S. Geological Survey Techniques and Methods, book 11, chap. B7, 25 p. with appendixes, https://doi.org/10.3133/tm11B7.

Axler, R. P. \& J. E. Reuter, 1996. Nitrate uptake by phytoplankton and periphyton: whole-lake enrichments and mesocosm-15N experiments in an oligotrophic lake. Limnology and Oceanography 41: 659-671.

Beeton, A. M., 2002. Large freshwater lakes: present state, trends, and future. Environmental Conservation 29: 21-38.

Biggs, B. J. F. \& H. A. Thomsen, 1995. Disturbance of stream periphyton by perturbation in shear stress: time to structural failure in community resistance. Journal of Phycology 31: 233-241.

Biggs, B. J. \& C. Kilroy, 2000. Stream Periphyton Monitoring Manual. http://www.epa.gov/climatechange/fq/ emissions.html\#q7.

Bonferroni, C. E., 1936. 1936 Teoria Statistica Delle Classi e Calcolo Delle Probabilità. Pubblicazioni Del R Istituto Superiore Di Scienze Economiche e Commerciali Di Firenze 8: 3-62 (Italian).

Bothwell, M. L. \& C. Kilroy, 2011. Phosphorus limitation of the freshwater benthic diatom didymosphenia geminata determined by the frequency of dividing cells. Freshwater Biology 56: 565-578.

Cantonati, M., D. Metzeltin, N. Soninkhishig \& H. LangeBertalot, 2016. Unusual occurrence of a Didymosphenia bloom in a lentic habitat: observation of Didymosphenia laticollis blooming on the eastern shore of Lake Hövsgöl (Mongolia). Phytotaxa 263: 139-146.

Clark, R. P., M. S. Edwards \& M. S. Foster, 2004. Effects of shade from multiple kelp canopies on an understory algal assemblage. Marine Ecology Progress Series 267: 107-119.

Collins, G. B. \& C. I. Weber, 1978. Phycoperiphyton (Algae) as indicators of water quality. Transactions of the American Microscopical Society 97: 36-43.

Denicola, D. M. \& M. Kelly, 2013. Role of periphyton in ecological assessment of lakes. Freshwater Science 33: 619-638.

Dunn, O. J., 1964. Multiple comparisons using rank sums. Technometrics 6: 241-252.

Flint, R. W. \& C. R. Goldman, 1975. The effects of a benthic grazer on the primary productivity of the littoral zone of Lake Tahoe. Limnology and Oceanography 20: 935-944. 
Goldman, C. R., 1974. Eutrophication of Lake Tahoe, Emphasizing Water Quality. United State Environmental Protection Agency, Corvallis.

Goldman, C. R., 1967. The bad news from Lake Tahoe. Cry California 3: 12-23.

Goldman, C. R. \& E. De Amezaga, 1975. Spatial and temporal changes in the primary productivity of Lake Tahoe, California-Nevada between 1959 and 1971. SIL Proceedings 1922-2010(19): 812-825.

Goldman, C. R., A. D. Jassby \& S. H. Hackley, 1993. Decadal, interannual, and seasonal variability in enrichment bioassays at Lake Tahoe, California-Nevada, USA. Canadian Journal of Fisheries and Aquatic Science 50: 1489-1496.

Hackley, S. H., S. Watanabe, K. J. Senft, Z. Hymanson, S. G. Schladow \& J.E. Reuter, 2016. Evaluation of Trends in Nearshore Attached Algae: 2015 TRPA Threshold Evaluation Report Final Report.

Hackley, S. H., B. C. Allen, D. A. Hunter \& J.E. Reuter, 2004. Lake Tahoe Water Quality Investigations: Algal Bioassay, Phytoplankton, Atmospheric Nutrient Deposition, Periphyton.

Hawes, I. \& R. Smith, 1994. Seasonal dynamics of epilithic periphyton in oligotrophic Lake Taupo, New Zealand. New Zealand Journal of Marine and Freshwater Research 28: $1-12$.

Hecky, R. E. \& R. H. Hesslein, 1995. Contributions of benthic algae to lake food webs as revealed by stable isotope analysis. Journal of the North American Benthological Society 14: 631-653.

Higgins, S. N., S. Y. Malkin, E. T. Howell, S. J. Guildford, L. Campbell, V. Hiriart-Baer \& R. E. Hecky, 2008. An ecological review of Cladophora glomerata (Chlorophyta) in the Laurentian Great Lakes. Journal of Phycology 44: 839-854.

Hoagland, K. D., J. R. Rosowski, M. R. Gretz \& S. C. Roemer, 1993. Diatom extracellular polymeric substances: function, fine structure, chemistry, and physiology. Journal of Phycology 29: 537-566.

Hyne, N. J., P. Chelminski, J. E. Court, D. S. Gorsline \& C. R. Goldman, 1972. Quaternary history of Lake Tahoe, California-Nevada. Geological Society of America Bulletin 83: 1435-1448.

Iwamura, T., H. Nagai \& S. E. Ichimura, 1970. Improved methods for determining contents of chlorophyll, protein, ribonucleic acid, and deoxyribonucleic acid in planktonic populations. Internationale Revue Der Gesamten Hydrobiologie Und Hydrographie 55: 131-147.

Jacoby, J. M., D. D. Bouchard \& C. R. Patmont, 1991. Response of periphyton to nutrient enrichment in Lake Chelan, WA. Lake and Reservoir Management 7: 33-43.

Johnson, R. E., N. C. Tuchman \& C. G. Peterson, 1997. Changes in the vertical microdistribution of diatoms within a developing periphyton mat. Journal of the North American Benthological Society 16: 503-519.

Kendall, M. G., 1975. Rank correlation methods, 4th ed. Charles Griffin \& Co., Ltd., London.

Kilroy, C. \& M. L. Bothwell, 2014. Attachment and short-term stalk development of Didymosphenia geminata: effects of light, temperature and nutrients. Diatom Research 29: 237-248.
Kravtsova, L. S., L. A. Izhboldina, I. V. Khanaev, G. V. Pomazkina, E. V. Rodionova, V. M. Domysheva, M. V. Sakirko, I. V. Tomberg, T. Y. Kostornova, O. S. Kravchenko \& A. B. Kupchinsky, 2014. Nearshore benthic blooms of filamentous green algae in Lake Baikal. Journal of Great Lakes Research 40: 441-448.

Kruskal, W. H. \& W. A. Wallis, 1952. Use of ranks in onecriterion variance analysis. Journal of the American Statistical Association 47: 583-621.

Lahontan Regional Water Quality Control Board (LRWQCB) \& Nevada Division of Environmental Protection (NDEP), 2010. Lake Tahoe Total Maximum Daily Load Technical Report. California - Lahontan Water Board and Nevada Division of Environmental Protection.

Lambert, D., A. Cattaneo \& R. Carignan, 2008. Periphyton as an early indicator of perturbation in recreational lakes. Canadian Journal of Fisheries and Aquatic Sciences 65: 258-265.

Leonard, R. L., L. A. Kaplan, J. F. Elder, R. N. Coats \& C. R. Goldman, 1979. Nutrient transport in surface runoff from a subalpine watershed, Lake Tahoe Basin, California. Ecological Monographs 49: 281-310.

Loeb, S. L., 1987. Groundwater Quality Within the Tahoe Basin University of California. University of California, Davis, Institute of Ecology, Davis.

Loeb, S. L., 1981. An in situ method for measuring the primary productivity and standing crop of the epilithic periphyton community in lentic systems. Limnology and Oceanography 26: 394-399.

Loeb, S. L., 1980. The Production of the Epilithic Periphyton Community in Lake Tahoe. University of California, Davis, California-Nevada.

Loeb, S. L. \& J. E. Reuter, 1984. Littoral Zone Investigations, Lake Tahoe 1982 - Periphyton.

Loeb, S. L., J. E. Reuter \& C. R. Goldman, 1983. Littoral zone production of oligotrophic lakes. Developments in Hydrobiology 17: 161-167.

Mann, H. B., 1945. Mann nonparametric test against trend. Econometrica 13: 245-259.

Multi-Resolution Land Characteristics Consortium (MRLC), 2011. National Land Cover Database 2011.

Naranjo, R. C., R. G. Niswonger, D. Smith, D. Rosenberry \& S. Chandra, 2019. Linkages between hydrology and seasonal variations of nutrients and periphyton in a large oligotrophic subalpine lake. Journal of Hydrology 568: $877-890$

National Drought Mitigation Center, 2020. Drought in California. https://www.drought.gov/drought/states/california.

R Team, 2013. R Development Core Team. R: A Language and Environment for Statistical Computing.

Reuter, J. E., S. L. Loeb \& C. R. Goldman, 1986a. The physiological ecology of nuisance algae in an oligotrophy lake. Studies in Environmental Science 28: 115-127.

Reuter, J. E., S. L. Loeb \& C. R. Goldman, 1986b. Inorganic nitrogen uptake by epilithic periphyton in an N-deficient lake. Limnology and Oceanography 31: 149-160.

Roberts, D. C., P. Moreno-Casas, F. A. Bombardelli, S. J. Hook, B. R. Hargreaves \& S. G. Schladow, 2019. Predicting wave-induced sediment resuspension at the perimeter of lakes using a steady-state spectral wave model. Water Resources Research 55: 1279-1295. 
Rosenberger, E. E., S. E. Hampton, S. C. Fradkin \& B. P. Kennedy, 2008. Effects of shoreline development on the nearshore environment in large deep oligotrophic lakes. Freshwater Biology 53: 1673-1691.

Sahoo, G. B., D. M. Nover, J. E. Reuter, A. C. Heyvaert, J. Riverson \& S. G. Schladow, 2013. Nutrient and particle load estimates to Lake Tahoe (CA-NV, USA) for total maximum daily load establishment. Science of The Total Environment 444: 579-590.

Spitale, D., A. Scalfi \& M. Cantonati, 2014. Urbanization effects on shoreline phytobenthos: a multiscale approach at lake extent. Aquatic Sciences 76: 17-28.

Tahoe Environmental Research Center (TERC), 2018. Tahoe: State of The Lake Report 2018. https://tahoe.ucdavis.edu/ sites/g/files/dgvnsk4286/files/inline-files/ SOTL_Complete_reduced_4.pdf.

Tahoe Environmental Research Center (TERC), 2019. Tahoe: State of the Lake Report 2019. https://tahoe.ucdavis.edu/
sites/g/files/dgvnsk4286/files/inline-files/SOTL2019_ reduced.pdf.

United States Army Corps of Engineers (USACE), 2003. Lake Tahoe Basin Framework Study: Groundwater Evaluation.

United States Geological Survey (USGS), 2019. National Water Information System. USGS 10337000 Lake Tahoe A Tahoe City CA.

Vadeboncoeur, Y. \& A. D. Steinman, 2002. Periphyton function in Lake Ecosystems. The Scientific World Journal 2: 1449-1468.

Weitzel, R. L. ed., 1979. Methods and Measurements of Periphyton Communities: A Review. ASTM International 690.

Yoshii, K., 1999. Stable isotope analyses of benthic organisms in Lake Baikal. Hydrobiologia 411: 145-159.

Publisher's Note Springer Nature remains neutral with regard to jurisdictional claims in published maps and institutional affiliations. 